\title{
PUSAT PELATIHAN KARAKTER UNTUK MILENIAL
}

\author{
Venessa Handiwinata ${ }^{1)}$, Budi Adelar Sukada ${ }^{2)}$ \\ 1)Program Studi S1 Arsitektur, Fakultas Teknik, Universitas Tarumanagara, venessa.handiwinata@gmail.com \\ 2) Program Studi S1 Arsitektur, Fakultas Teknik, Universitas Tarumanagara, budisukada@yahoo.com
}

\begin{abstract}
Abstrak
Generasi millennial adalah generasi kelahiran sekitar tahun 1980 sampai dengan 2000 dan sedang dalam usia produktif. Generasi ini memiliki sebuah isu, dimana mereka cenderung malas, tidak fokus dan narsis. Terdapat 4 faktor penyebabnya. Pertama, generasi ini menjadi depresi saat di dunia kerja karena tidak adanya bantuan dari orangtua dan tidak mendapatkan apa yang mereka inginkan; kedua, generasi ini cenderung kecanduan akan respon dari media sosial, dimana hal tersebut menyebabkan tidak adanya relasi yang kuat antar individu; ketiga, mereka cenderung tidak bertahan lama dalam suatu perusahaan karena mereka merasa tidak mendapatkan apa yang mereka inginkan dan ingin semuanya serba instan (tidak sabaran); keempat, lingkungan hidup yang membentuk karakter dari individu, dimana lingkungan hidup pada saat ini lebih mementingkan angka dibandingkan kebutuhan masyarakat dan hanya memikirkan kebutuhan jangka pendek. Selain itu, perusahaan tempat mereka bekerja cenderung tidak membantu/menyediakan fasilitas untuk membangun skill kerjasama dan pembangunan karakter. Dari semua isu tersebut, generasi millennial membutuhkan sebuah fasilitas untuk mengembangkan social skills mereka, dimana hal tersebut dapat mempengaruhi mereka dalam pembentukan visi hidup yang berhubungan dalam pengembangan potensi dan inovasi mereka. Oleh sebab itu, mereka membutuhkan suatu Character Training Center, dengan fasilitas pendukung seperti foodhall, co-working space dan fasilitas gym, dimana fasilitas pendukung tersebut dapat membantu sebuah proses character training. Character Training Center ini memiliki konsep dimana mengutamakan togetherness and sociability dengan metode "the c's".
\end{abstract}

Kata kunci: Kolaborasi; Komunikasi; Kreatif; Peduli; Pilihan; Pemikiran Kritis

\begin{abstract}
Millennial generation is the generation of births around 1980 to 2000 and in productive age. This generation has a problem, where they tend to be lazy, out of focus and narcissistic. There are 4 factors that cause it. First, this generation becomes depressed when in the workforce because there is no help from their parents and does not get what they want; second, this generation requires an addiction to the response of social media, which causes the absence of relations that improve between individuals; third, they do not last long in a company because they do not get what they want and want everything to be instant (inpatient); fourth, environmental participation that creates character of the individuals, where the environment at this time is more concerned with numbers than a community needs and only focus on shortterm needs. In addition, the companies where they work don't help/provide facilities to build cooperation and character development skills. Of all these problems, the millennial generation needs a facilities to develop their social skills, which can improve their ability to develop visions related to the development of their potential and innovation. Therefore, they need a character training center, with supporting facilities such as foodhall, shared work space, and gym facilities, where those supporting facilities can help the process of character training. This character training center has a concept that prioritizes togetherness and sociability with the "the c's" method.
\end{abstract}

Keyword: Caring; Choice; Collaboration; Communication; Creativity; Critical Thinking 


\section{PENDAHULUAN}

Generasi millennial adalah generasi yang berkelahiran tahun 1980 sampai 2000, dimana pada saat ini berumur sekitar 20-39 tahun. Generasi ini tertuduh sebagai generasi yang malas, narsis, dan tidak fokus. Generasi ini pun memiliki keinginan untuk bekerja dan menghasilkan keuntungan, tetapi untuk beberapa alasan mereka tidak bahagia atau puas dengan apa yang mereka kerjakan. Hal tersebut terjadi kepada mereka karena beberapa faktor sebagai berikut :

\section{Parenting}

Didikan orangtua maupun guru merupakan hal yang sangat penting karena didikan tersebut akan tertanam seumur hidup. Namun, terdapat beberapa orangtua atau guru yang melakukan didikan yang salah, yang dapat berakibat fatal untuk masa depan seorang anak jika tidak dapat diatasi.

Saat kecil, anak-anak sering kali dibanggakan dengan kata-kata bahwa mereka adalah anak yang "spesial"; mereka memiliki apa pun yang mereka inginkan dalam hidup hanya karena mereka menginginkannya; mereka masuk dalam kelas unggulan karena keinginan orangtua mereka, dan mendapatkan nilai $\mathrm{A}$ karena para guru tidak ingin berurusan dengan orangtua murid, namun mereka yang bekerja keras berada di posisi bawah dan merasakan malu juga lebih buruk.

Saat anak-anak lulus dari dunia pendidikan, mulai mendapatkan pekerjaan dan memasuki dunia luar, tetapi mereka mengetahui bahwa tidak ada yang spesial pada dirinya dan orangtua mereka tidak dapat membantu mereka dalam posisi pekerjaan mereka, akan menyebabkan mereka tidak mendapatkan apa-apa pada posisi terbawah dan juga mereka tidak bisa memiliki sesuatu karena mereka menginginkannya. Hal tersebut menyebabkan citra diri mereka hancur dan tumbuh dengan harga diri yang lebih rendah dari generasi sebelumnya.

Masalah lainnya adalah dimana generasi ini sangat pandai dalam menggunakan media sosial, dengan kata lain generasi ini pun pandai menunjukkan kepada masyarakat bahwa hidup mereka sangat baik walaupun sebenarnya kehidupan mereka sulit. Oleh sebab itu, semua orang terlihat seperti kuat dan selalu dapat menghadapi masalah yang mereka hadapi dimana kebanyakan dari mereka memiliki kenyataan yang merupakan kebalikan dari semua itu, dan kebanyakan dari mereka clueless, tetapi dihadapan masyarakat mereka dapat mengatasi masalah mereka. Hal-hal tersebut bukan kesalahan mereka sendiri melainkan mereka dididik dalam didikan yang salah.

\section{Technology}

Media sosial dan handphone merupakan teknologi yang memiliki unsur kecanduan, dan kita akan merasakan suatu kesenangan saat kita mendapatkan sebuah respon (seperti chat dan like pada Instagram). Sebagai contoh, saat kita mem-posting sebuah gambar pada Instagram, dan terjadi kelambatan untuk jumlah likes, yang terpikirkan adalah "apakah saya melakukan kesalahan?"; "apa yang saya lakukan?"; "apakah mereka tidak suka lagi dengan saya?". Hal tersebut terjadi karena "afraid to be unfriended".

Tidak adanya larangan ataupun batasan untuk media sosial dan handphone, dan tidak ada yang salah menggunakan kedua hal tersebut, hanya pemakaian yang berlebihan dan cara penggunaan yang salah dan menyebabkan kecanduan atau ketagihan, terjadinya ketidakseimbangan. Sebagai contoh, kita bertemu dengan teman kita tetapi kita chatting dengan teman kita yang tidak ada bersama kita pada saat itu. Ada terjadinya sebuah ketagihan dengan media sosial yang dapat menghancurkan relasi atau hubungan dengan orang lain dan dapat menyebabkan hidup menjadi lebih buruk.

Hal tersebut dapat memperburuk kehidupan dikarenakan tidak pernah melatih untuk membangun sebuah relasi. Banyak dari generasi ini tidak tahu cara untuk membangun relasi yang kuat dan bermakna, karena mereka beranggapan bahwa relasi atau pertemanan adalah sesuatu yang dangkal dan mereka tidak mengandalkan teman atau orang lain. Walaupun di dunia nyata mereka bersenang-senang dengan teman-teman mereka, tetapi mereka juga mengetahui bahwa suatu saat teman-teman mereka akan meninggalkan mereka jika ada sesuatu yang lebih baik dari mereka. Oleh sebab itu, tidak adanya relasi yang kuat yang dibentuk dalam generasi ini. Dari 
permasalahan tersebut, akhirnya generasi ini jika mempunyai suatu masalah dalam kehidupan mereka, mereka cenderung mencari media sosial daripada "seorang teman" untuk bantuan.

Pada saat ini, semua serba instan kecuali untuk kepuasan atas pekerjaan dan sebuah relasi yang kuat, tidak ada aplikasi untuk hal tersebut. Kedua hal tersebut merupakan sesuatu yang memiliki proses yang cukup lama, tidak nyaman dan rumit. Oleh sebab itu, muncul faktor berikutnya yaitu ketidaksabaran.

\section{Impatience}

Ketidaksabaran akan kepuasan atas pekerjaan terjadi pada generasi ini. Generasi ini mudah dan cepat untuk keluar dari suatu perusahaan, dan hanya bertahan kurang dari delapan bulan. Hal tersebut dikarenakan mereka tidak membuat suatu "impact", tidak adanya kemajuan dari sesuatu yang mereka telah kerjakan. Sebuah goal dapat dicapai dengan mendaki gunung yang ada di depan kita, tetapi generasi ini tidak melihat "gunung" tersebut, mereka hanya tertuju kepada goal yang mereka inginkan.

Hal yang mereka tidak miliki adalah kesabaran. Hal-hal seperti kasih sayang, pemenuhan pekerjaan, percaya diri, dan skill membutuhkan waktu untuk mencapainya. Proses yang harus dilewati untuk mencapai semua itu merupakan proses yang panjang dan sulit.

Oleh sebab itu jika tidak meminta bantuan, mempelajari atau mendalami skill tersebut, akan sangat sulit atau tidak akan mencapai titik puncak "gunung" tersebut dan jatuh. Yang akan terjadi jika berada di posisi tersebut yaitu yang terburuk adalah menjadi depresi dan yang lainnya adalah tetap menjalani hidup, tetapi tidak ada visi untuk meningkatkan kualitas hidup dan tidak adanya "kebahagiaan" dalam hidup mereka. Hal tersebut bukan kesalahan mereka sendiri dan mengarahkan ke faktor berikutnya yaitu lingkungan hidup.

\section{Environment}

Lingkungan hidup saat ini lebih mementingkan "angka" daripada masyarakat. Mereka lebih mementingkan keuntungan jangka pendek daripada untuk kehidupan jangka panjang. Mereka berada di lingkungan perusahaan yang tidak membantu mereka dalam membentuk rasa percaya diri mereka, tidak membantu membangun skill kerja sama, tidak membantu menemukan suatu keseimbangan, juga tidak membantu menyadarkan mereka bahwa tidak ada sesuatu yang instan di dunia ini dan perlu bekerja keras untuk mencapai suatu goal.

Oleh sebab itu, generasi ini sering menyalahkan diri mereka sendiri, yang pada kenyataannya bukan kesalahan dari mereka melainkan kurangnya kepemimpinan yang baik, dimana merupakan tanggung jawab dari sebuah perusahaan. Yang membuat hal tersebut lebih buruk adalah tidak adanya dukungan dari masyarakat dan orangtua mereka.

Permasalahan tersebut juga diungkapkan dalam The Deloitte Millennial Survey (2018) (dalam sektor bisnis/usaha yaitu generasi millennial terhadap pekerjaannya). Bisnis pada saat ini hanya fokus kepada agenda masing-masing daripada memikirkan masyarakat luas dan juga tidak ada ambisi lain selain menghasilkan uang.

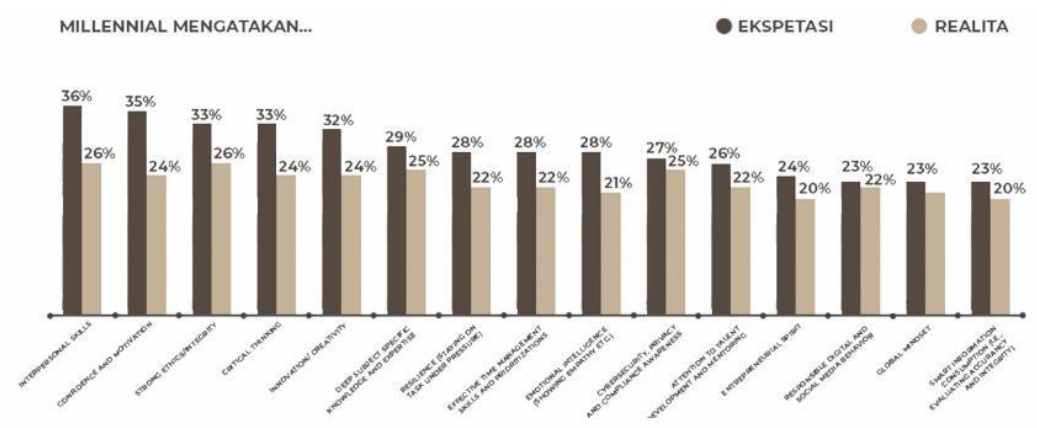

Tabel 1. Survey Kebutuhan Milenial akan Fasilitas Pelatihan Sumber: Deloitte, 2019 
Dampak dari tidak ada/kurangnya wadah tersebut, menyebabkan generasi ini memiliki kesabaran yang rendah dalam mencapai goal mereka. Tidak adanya motivasi yang tertanam pada mereka karena mereka tidak terarahkan dalam membentuk karakter dalam bekerja. Selain dari tidak adanya arahan dan pembentukkan karakter tersebut, mereka pun tidak dapat mengembangkan potensi mereka. Oleh karena itu, dibutuhkan sebuah wadah untuk membantu generasi milenial dalam pembentukan karakter yaitu sebuah Character Training center. Fasilitas tersebut dapat membantu mereka dalam mengembangkan social skills mereka seperti kepercayaan diri, relasi dan kesabaran. Social skills tersebut dapat mempengaruhi mereka dalam pembentukkan visi hidup, juga pengembangan potensi dan inovasi mereka kedepan.

\section{KAJIAN LITERATUR}

\section{Character Education}

Character education/pendidikan edukasi menjadi hal yang terpenting dalam edukasi. Dalam studi May dan Hartshorne, character education terdiri dari dua metode yaitu secara formal, direct method (berupa pengajaran) dan secara informal, indirect method (berupa kegiatan/aktivitas dan layanan yang disediakan). Untuk direct method, tidak baik jika sampai terjadi indoktrinasi atau mendikte perilaku moral seseorang. Sehingga dari studi tersebut, indirect method memiliki bobot lebih besar dari direct method, dimana karakter dapat terbentuk secara tidak langsung dalam sebuah kegiatan. Dalam kegiatan terdapat sebuah komunitas dan terjadi sosialisasi. Hal tersebut merupakan landasan utama dalam membantu membentuk karakter individu dimana terjadinya interaksi secara langsung dengan orang lain.

Seperti yang telah dijelaskan sebelumnya, character education merupakan salah satu kurikulum wajib dalam setiap sekolah (TK sampai dengan kelas 12). Kurikulum tersebut terdapat dua tipe yaitu secara formal dan informal. Dengan adanya kurikulum tersebut, dapat membantu membentuk kualitas mental dan moral yang mempengaruhi pikiran, perilaku dan budi pekerti. Hal tersebut dapat mengoptimalisasikan semua potensi dan bakat terpendam didalam diri untuk menjadi seorang pribadi yang sukses kedepannya, terutama dalam pekerjaan dan kehidupan pribadi.

Kunci untuk character education untuk masa yang akan datang adalah masyarakat itu sendiri, dengan konsep komunitas dalam edukasi tersebut. Selain itu, pendidikan tersebut tidak hanya sebatas sampai sekolah (TK sampai dengan kelas 12), tetapi mulai masuk ke bidang yang lain seperti universitas, bisnis, dan institusi lainnya.

\section{METODE}

Metode perancangan yang akan digunakan dalam proyek ini sebagai berikut : 1 . Mencari isu dari generasi milenial (behavior); 2. Menganalisa kebutuhan yang sesuai untuk menanggapi isu yang dibahas; 3. Menganalisa kebutuhan termasuk institusi apa yang sesuai; 4. Penyelesaian secara arsitektur(fungsi); 5. Melakukan studi preseden dan analisa prototype dan stereotype fungsi untuk mendapat kriteria desain; 6. Penyusunan program; 7. Analisa aktivitas dan konektivitas antara program utama dan program pendukung; 8. Pemilihan lokasi yang sesuai dalam menanggapi isu dan analisa tapak; 9 . Analisa zoning; 10. Proses perancangan.

Metode perancangan yang menjadi pertimbangan dalam desain adalah Homey. Dengan proyek ini yang memiliki fungsi sebagai sebuah training center, metode tersebut digunakan untuk menciptakan sebuah training center yang tidak seperti fasilitas edukasi atau pelatihan, yang bertujuan agar user atau pengguna tidak merasa tertekan dan dapat tidak menyadarkan mereka bahwa mereka sedang dalam proses pelatihannya.

\section{DISKUSI DAN HASIL}

Dari isu milenial yang dibahas, program utama pada proyek ini adalah dalam bidang edukasi. Edukasi yang dimaksud bukan merupakan edukasi seperti sekolah dasar, sekolah menengah, maupun perguruan tinggi. Edukasi pada proyek ini lebih mengarah kepada didikan atau 
pengarahan yang tidak didapatkan pada edukasi pada umumnya, yang membantu membentuk sebuah karakter seseorang dalam membangun sebuah visi hidup kedepannya.

Pada proyek ini, program utama yang akan diangkat sesuai dengan permasalahan yang dibahas sebelumnya adalah dalam bidang edukasi yang berfokus kepada bagian training center, yaitu sebuah character training center. Character training center ini bertujuan untuk menyediakan wadah untuk generasi ini, yang berfokus kepada pengarahan dan mentoring, juga pembentukan karakter individu dalam membangun sebuah visi hidup mereka, yang dapat mempengaruhi pengembangan potensi yang mereka miliki, dimana dapat terbangunnya sebuah inovasi baru, yang juga dapat dipengaruhi oleh relasi yang kuat (bersifat komunal). Target user untuk proyek ini adalah mahasiswa, fresh graduated student dan yang sudah bekerja.

Untuk lokasi terdapat beberapa kriteria yang sesuai dengan isu dan target user yaitu berada di dekat area universitas, area perkantoran dan transportasi umum yang terjangkau. Lokasi proyek yang sesuai dengan kriteria tersebut berada di Jl. Setiabudi Tengah, Kecamatan Setiabudi, Jakarta Selatan. Berikut analisis makro dan mikro lokasi proyek.

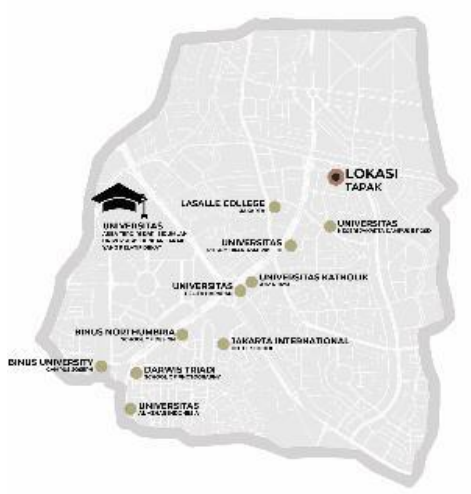

Universitas Sekitar Lokasi Tapak

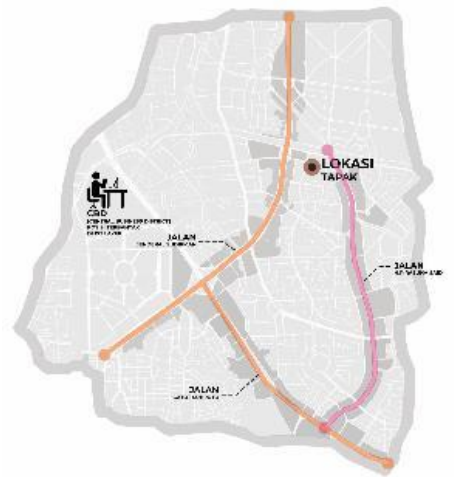

Area CBD Sekitar Lokasi Tapak

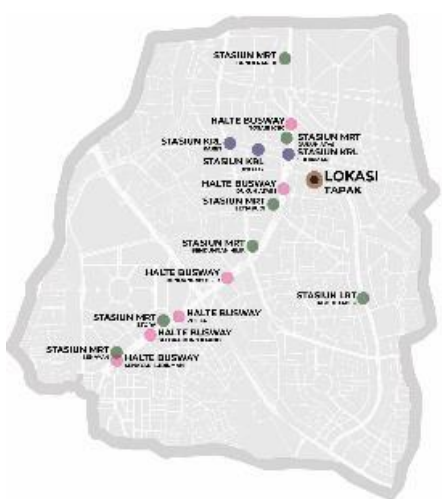

Transportasi Umum Sekitar Lokasi
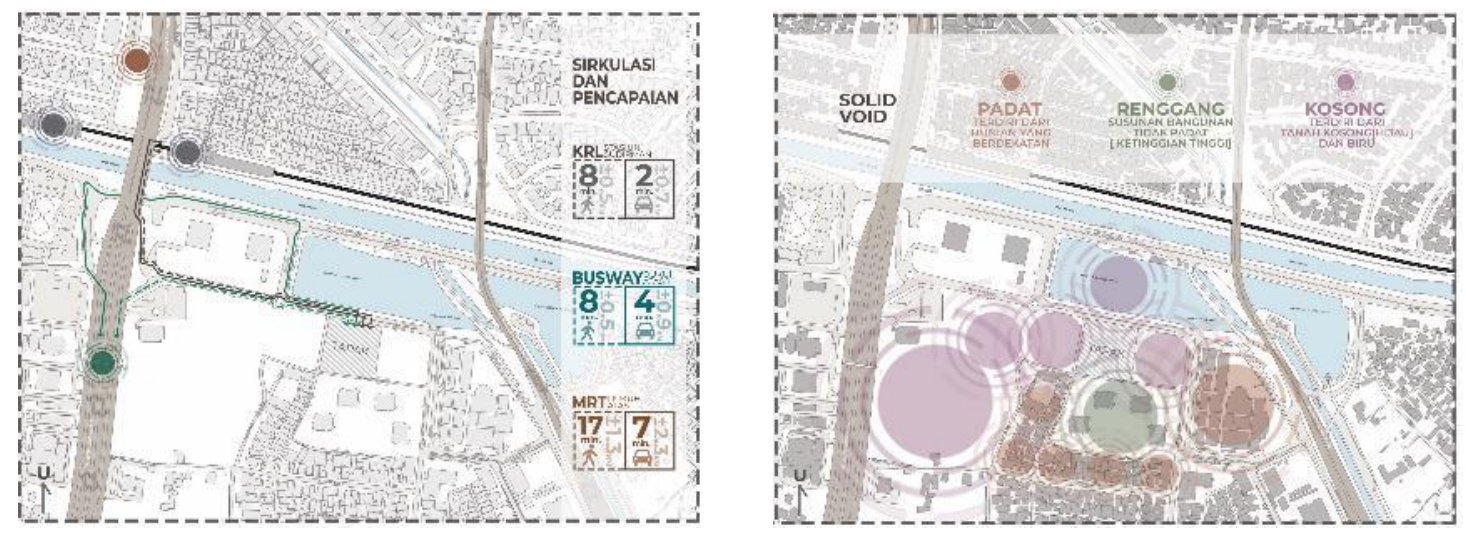

Gambar 1. Analisa Makro Lokasi

Sumber: Penulis, 2019 


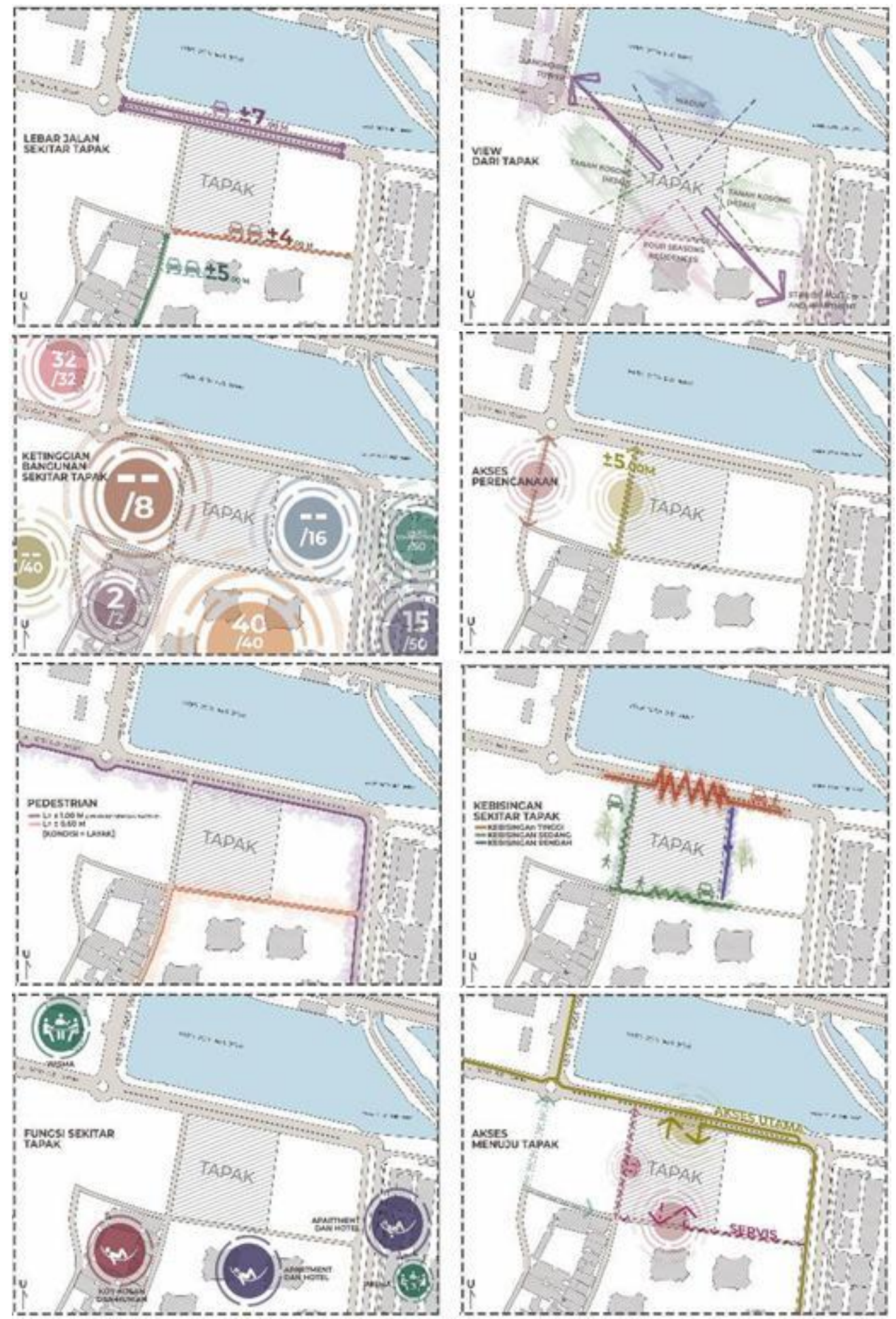

Gambar 2. Analisa Mikro Tapak

Sumber: Penulis, 2019 


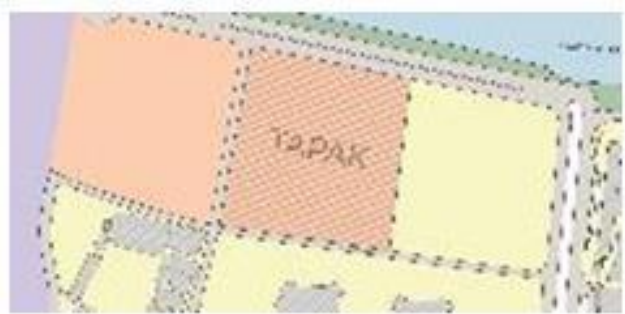

\section{Kecamatan - Setiabudi $\quad$ KDB dan KTB: $55 \%$ \\ Keluraban: Setiabudi \\ Zena: Campuran \\ $\mathrm{KLB} ; 3.00$ \\ $\mathrm{KB} ; 8$}

Id Subblek: 04.001.C.1.a.b.
$\mathrm{KDH} ; 30 \%$

\section{Gambar 3. Zonasi Lokasi}

Sumber: Penulis, 2019

Program utama dari proyek ini adalah sebuah Character Training Center dengan beberapa fasilitas pendukung yang mendukung program utama seperti foodhall dan café, sebagai fasilitas kebutuhan dan beristirahat; co-working, sebagai fasilitas untuk bekerja dan pencarian ide; dan gym, sebagai fasilitas untuk meningkatkan kebugaran fisik. Untuk fasilitas pendukung lainnya seperti hunian berasal dari sekitar tapak(kos-kosan, hunian, dan apartemen) yang dapat membantu pemasukkan lingkungan sekitar.

Pada Character Training Center terdapat kurikulum yang sesuai untuk menanggapi isu milenial tersebut dan terbagi dalam 3 zona utama yaitu caring (self-love, self-control, responsibility, diligence); collaboration (compassion, tolerance, respect, attentives); creativity (patienc, healthyliving).

Selain kurikulum terdapat beberapa tahapan (step by step) dalam sebuah pelatihan yaitu 1.pengenalan; 2.pemahaman; 3.penerapan; 4.pembiasaan; 5.pembudayaan(implementasi terhadap sosial); 6.internalisasi menjadi karakter. Untuk jenis kelas yang digunakan adalah kelas bersifat two directional education yang terdiri dari gathering space, small group class, private moment, dan private workspace.

Berikut diagram analisa desain proyek ini :
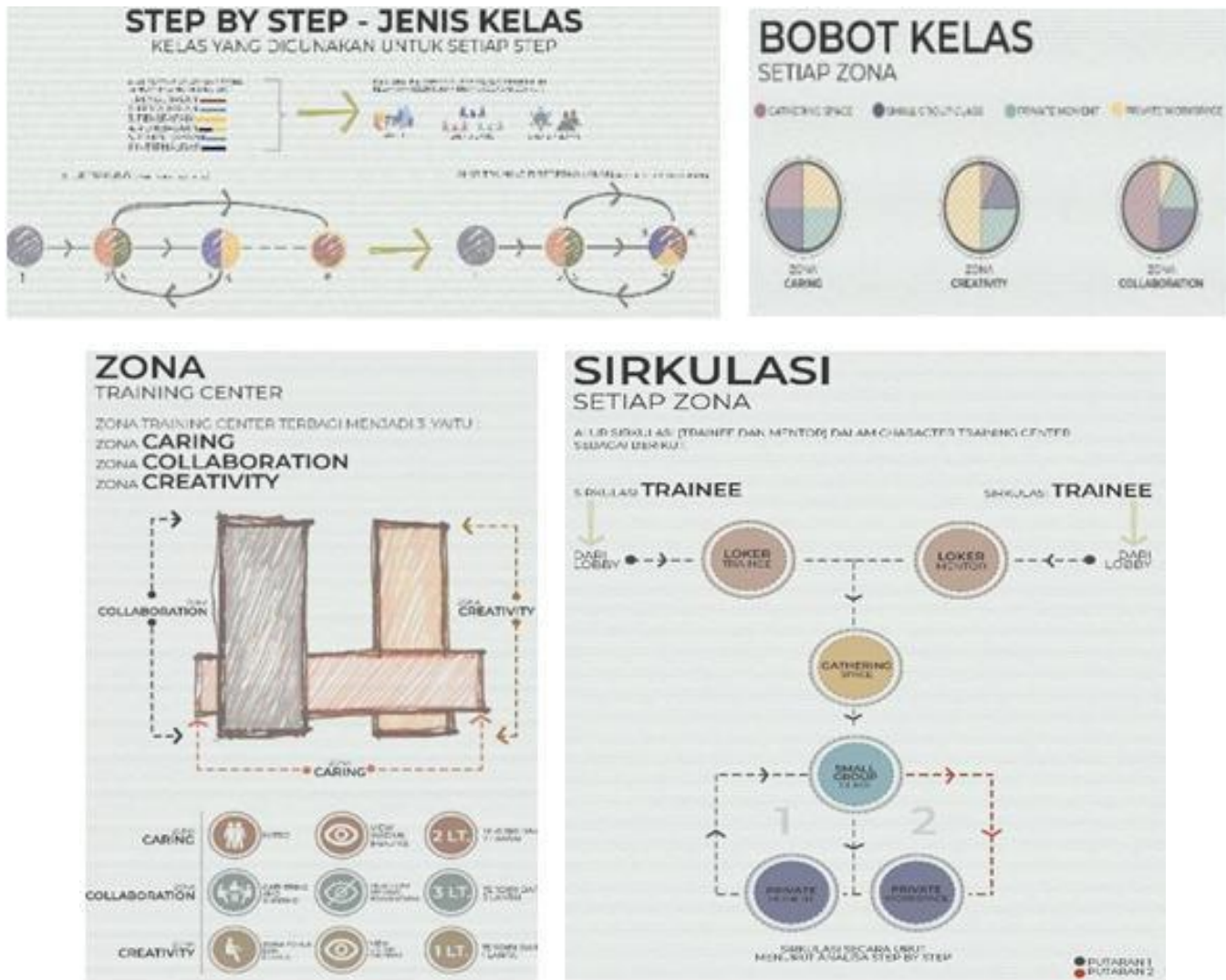

Gambar 4. Diagram Analisa Desain Proyek Sumber: Penulis, 2019 
Konsep design bangunan ini sebagai berikut. Hal pertama yang diperhatikan adalah dari tipologi bangunan dasar dari edukasi. Dari bentuk-bentuk tersebut (berdasarkan studi preseden), proses design mengambil bentuk dasar dan dilakukan duplikasi untuk 3 zona utama.
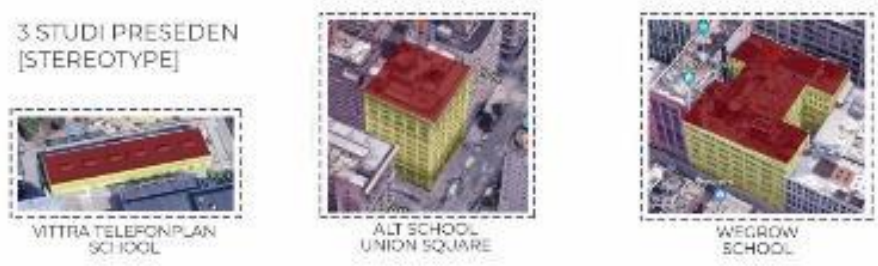

Gambar 5. Studi Preseden

Sumber : Google, 2019

Tahap selanjutnya adalah proses gubahan massa ,dengan tahap-tahap sebagai berikut :
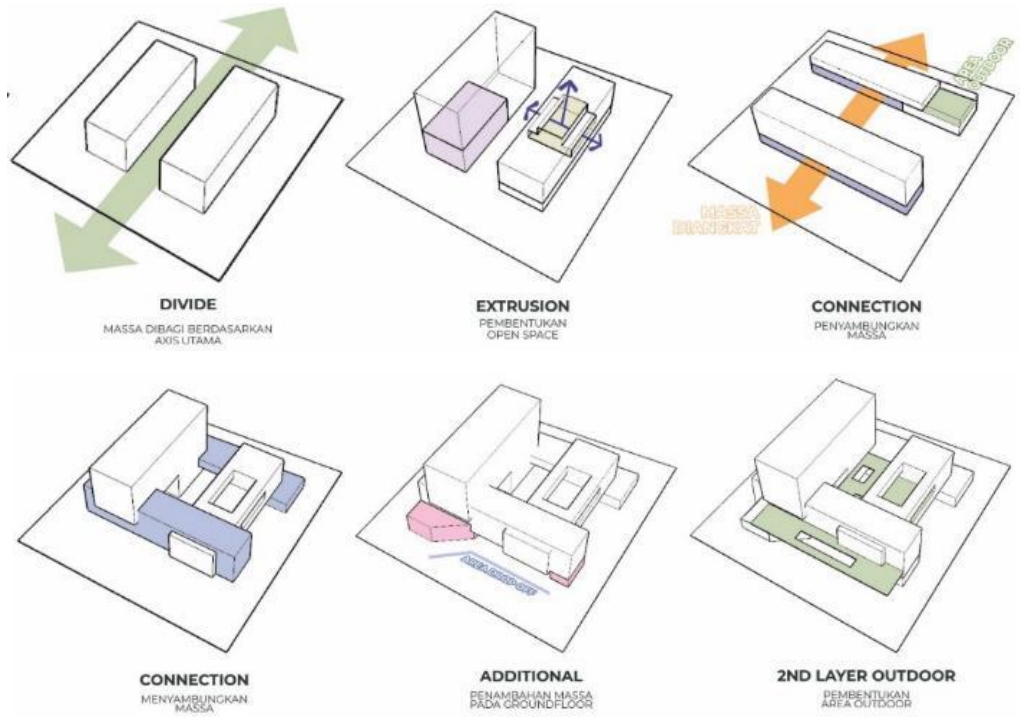

Gambar 6. Design Scheme

Sumber: Penulis, 2019

Terlihat bahwa setiap pertemuan antara massa diterapkan metode tembus dan menembus, yang mengumpamakan produk dari produk ini yaitu seorang entreprenuer, dengan sebuah visi "menembus batas menuju sukses tanpa batas" (sehingga beberapa massing yang terbentuk menembus satu sama lain).

Berikut gambaran visual dari proyek ini.

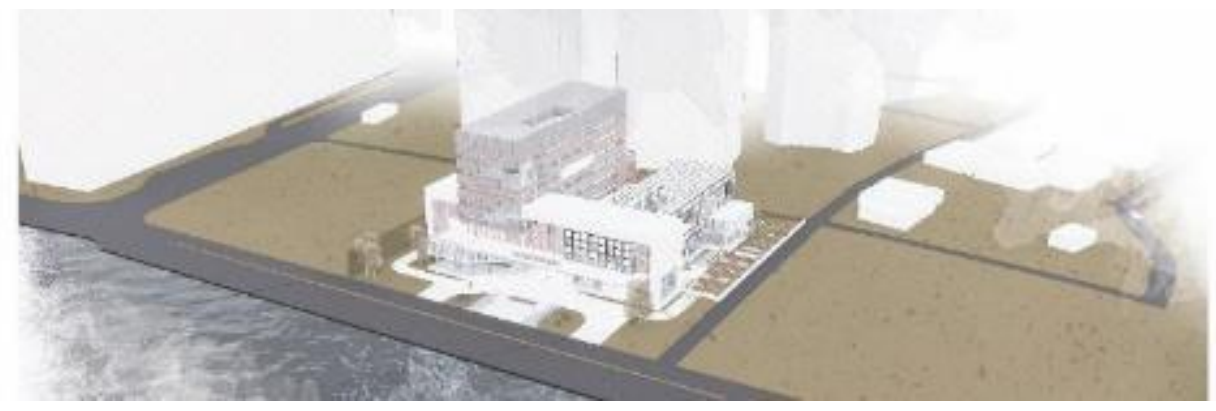

Gambar 7. Perspektif Eksterior

Sumber: Penulis, 2019 
Siteplan proyek sebagai berikut.

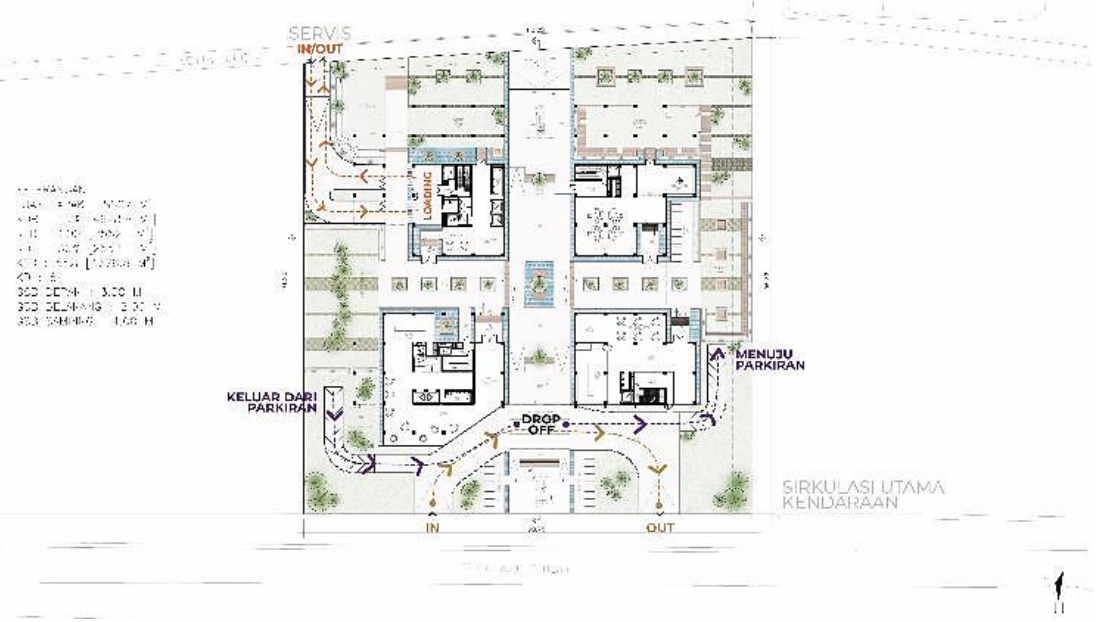

Gambar 8. Siteplan-Sirkulasi Utama Kendaraan Sumber: Penulis, 2019

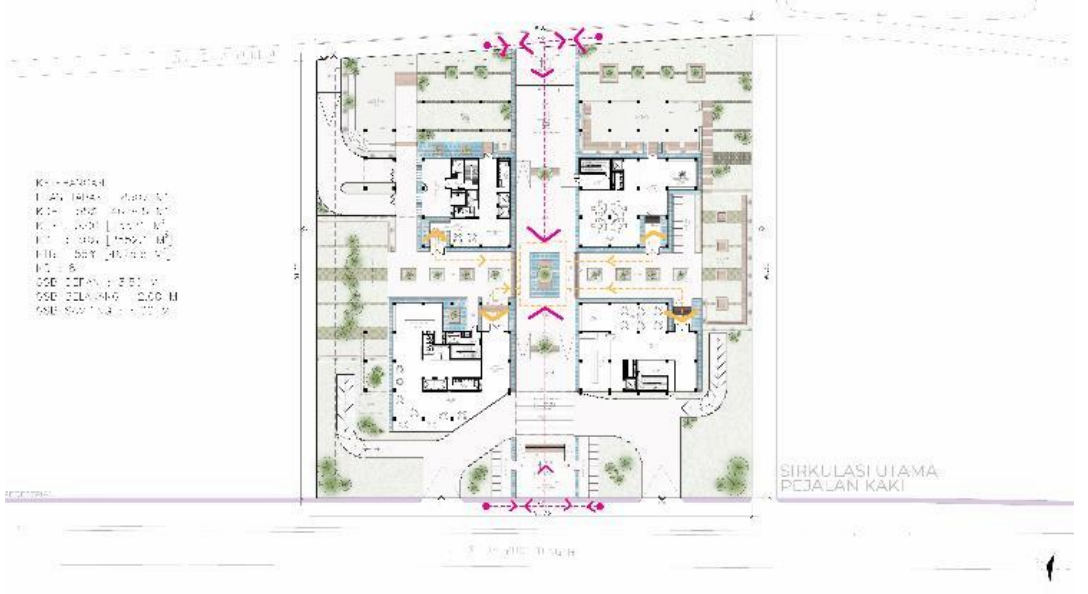

Gambar 9. Siteplan-Sirkulasi Utama Pejalan Kaki Sumber: Penulis, 2019

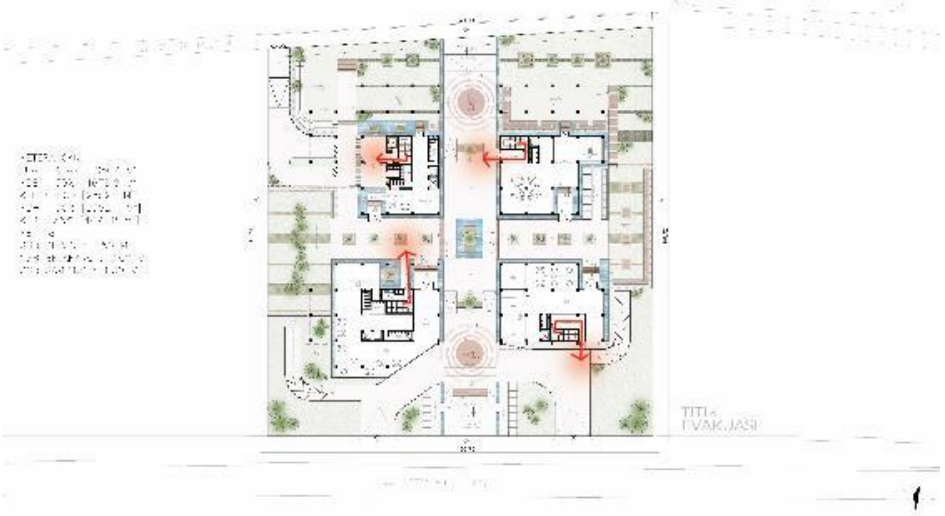

Gambar 10. Siteplan-Titik Evakuasi Sumber: Penulis, 2019 
Exploded denah proyek sebagai berikut :

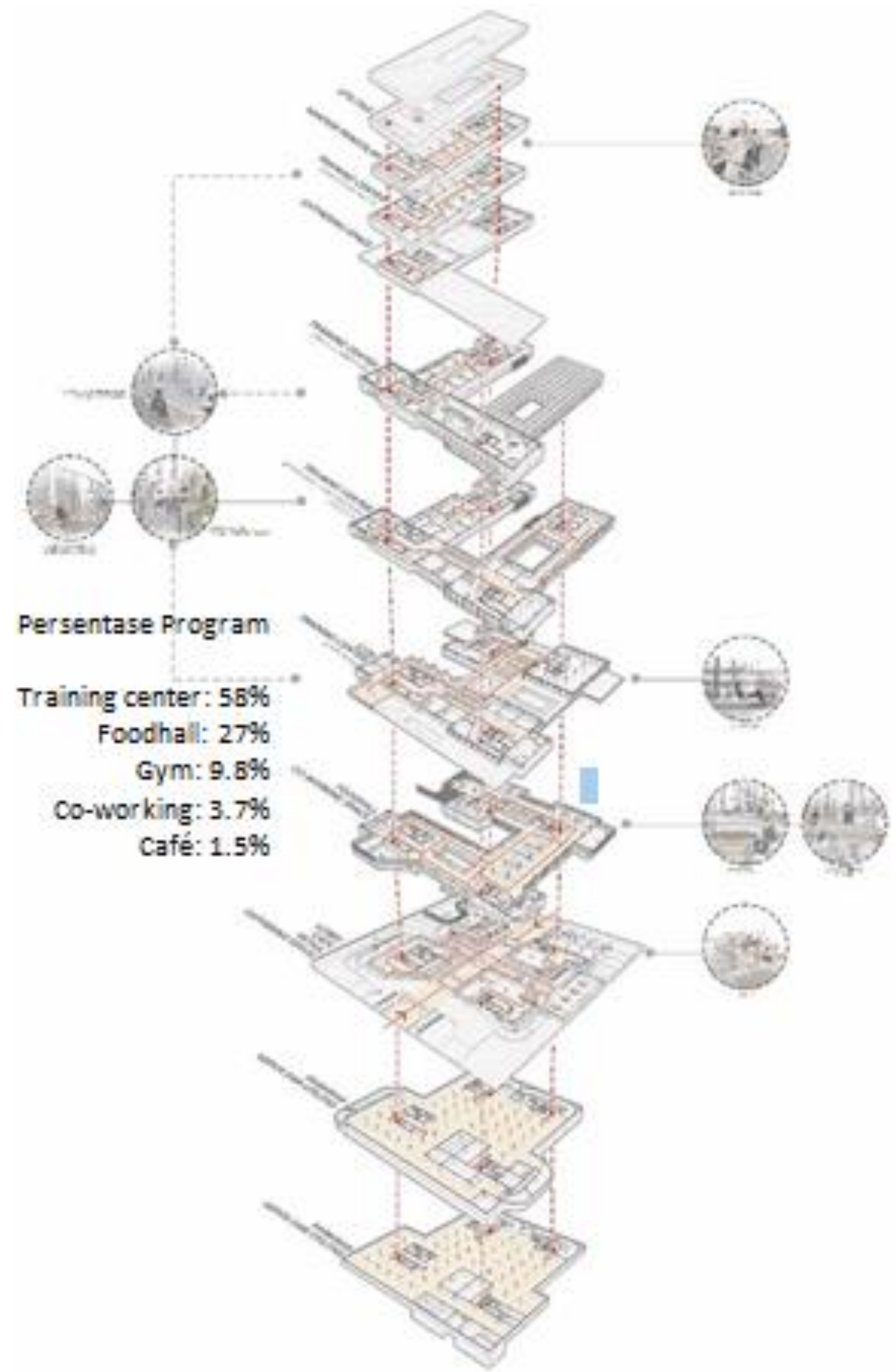

Gambar 11. Exploded Denah

Sumber: Penulis, 2019 

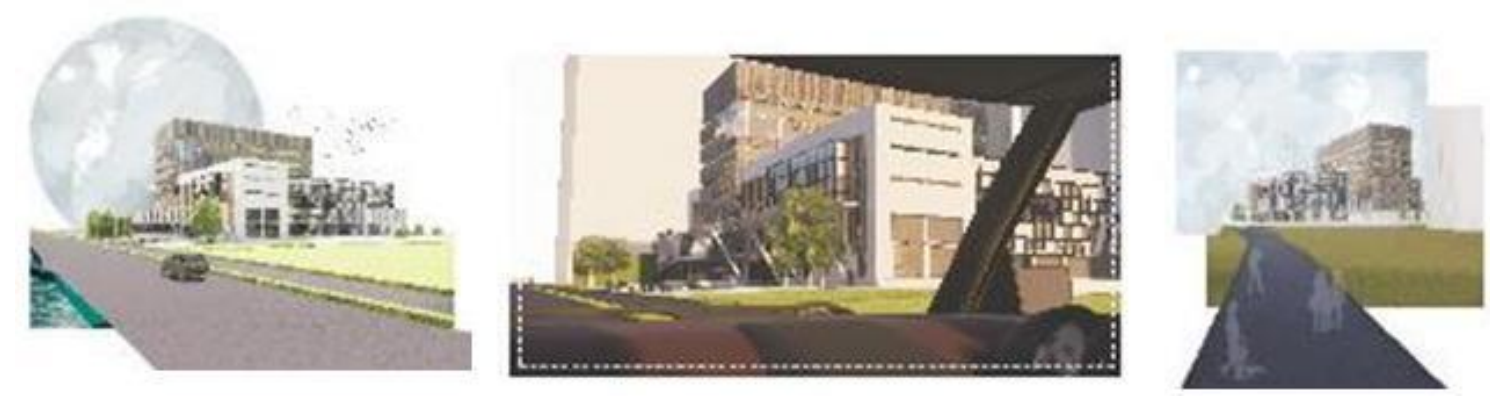

Gambar 12. 3D Eksterior

Sumber: Penulis, 2019

Tampak dan potongan proyek sebagai berikut.

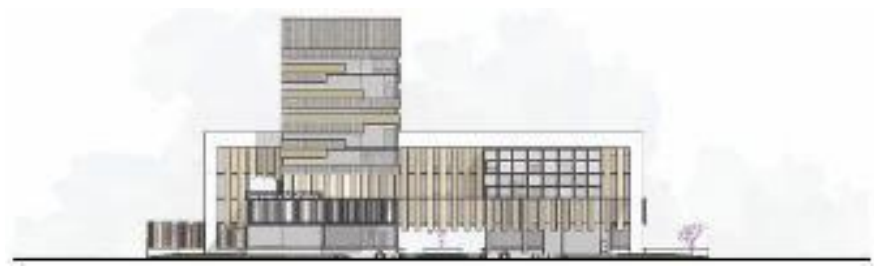

Gambar 13. Tampak Depan

Sumber: Penulis, 2019

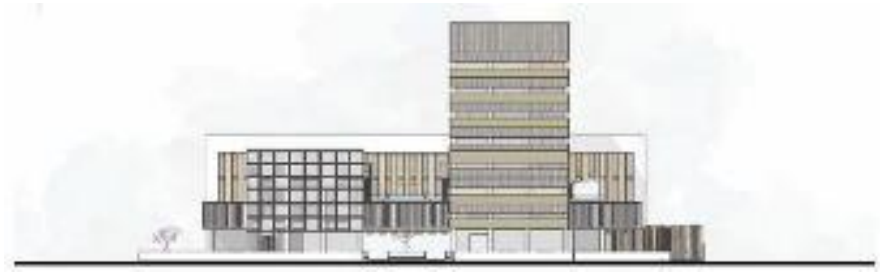

Gambar 14. Tampak Belakang

Sumber: Penulis, 2019

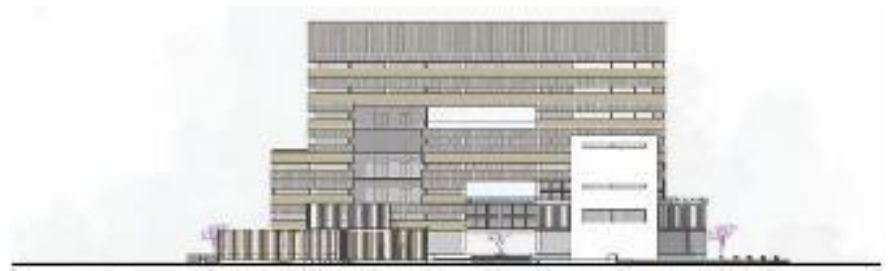

Gambar 15. Tampak S.Kanan

Sumber: Penulis, 2019

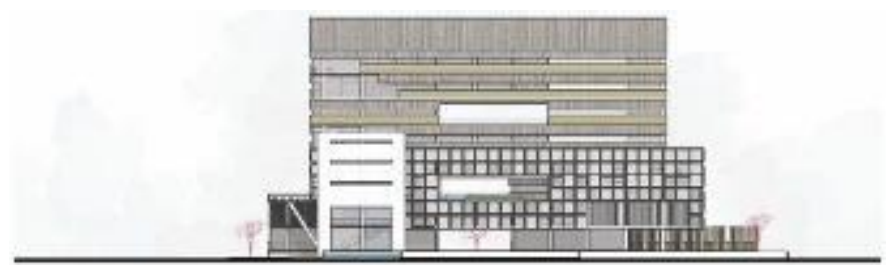

Gambar 16. Tampak S.Kiri

Sumber: Penulis, 2019 


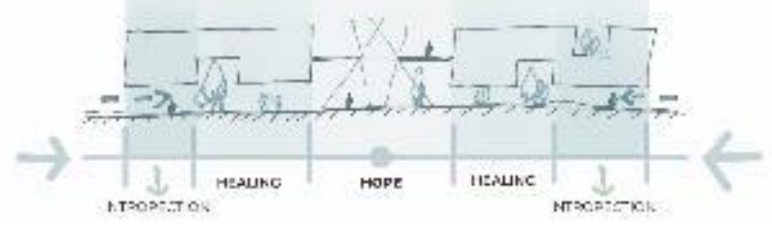

Gambar 17. Pengalaman Axis Utama

Sumber: Penulis, 2019
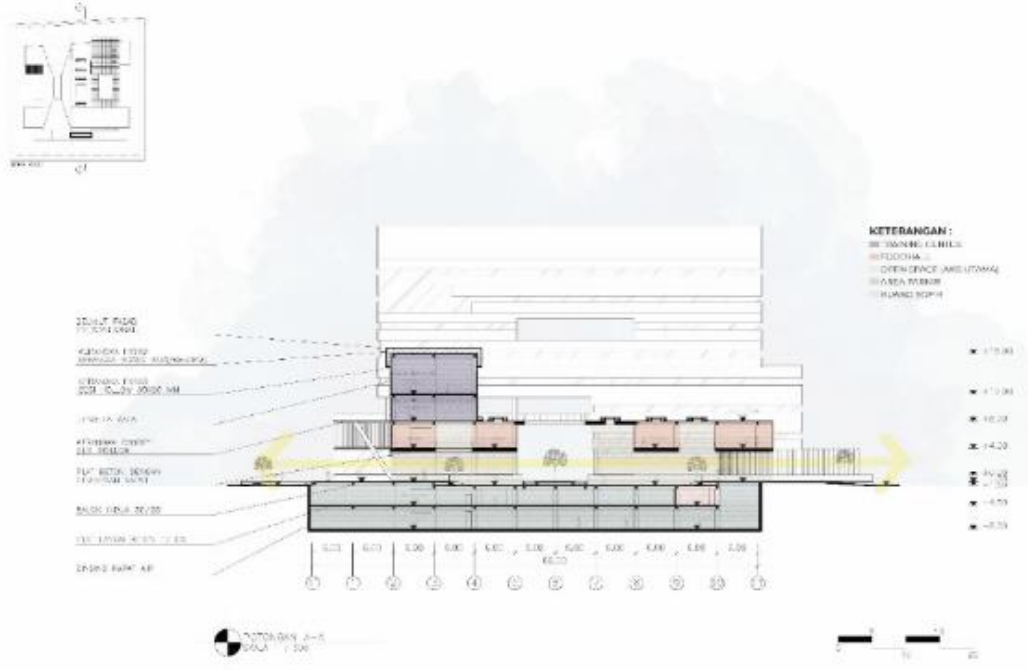

Gambar 18. Potongan A-A

Sumber: Penulis, 2019

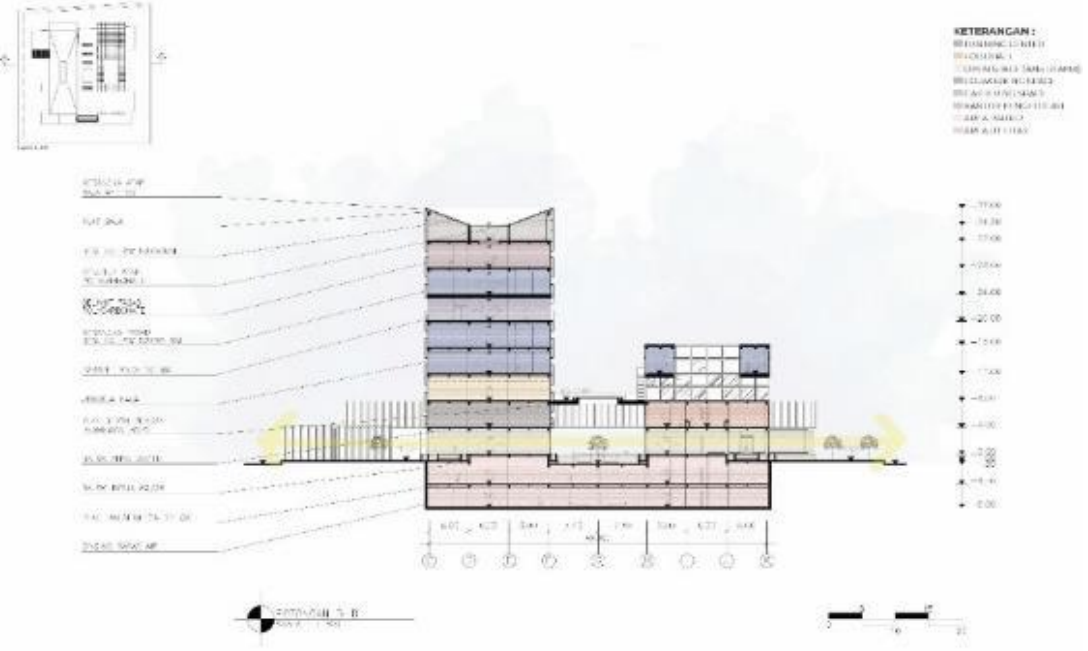

Gambar 19. Potongan B-B

Sumber: Penulis, 2019 


\section{KESIMPULAN DAN SARAN}

Proyek Character Training Center for Millennial di Jl. Setiabudi Tengah, Jakarta Selatan ini diharapkan dapat bermanfaat bagi lingkungan sekitar, terutama bagi generasi milenial yang mengalami isu dalam pembentukan karakter mereka, dimana isu tersebut mempengaruhi mereka dalam pembentukan visi hidup yang berdampak pada pengembangan potensi dan inovasi mereka. Melalui Character Training Center ini, masyarakat terutama generasi milenial dapat meningkatkan social skills mereka, seperti kepercayaan diri, relasi, dan kesabaran. Dengan menerapkan konsep Togetherness and Sociability, juga the c's, diharapkan terjadinya interaksi satu sama lain, baik sesama trainee maupun dengan mentor, berupa relasi yang kuat dan menciptakan suatu teamwork environment.

Untuk merancang proyek seperti ini perlu memperhatikan beberapa hal seperti sirkulasi, kebutuhan kelas berdasarkan jenisnya, dan pengalaman ruang yang ingin dicapai pada bangunan. Hal tersebut mempengaruhi keefektivitasan, kenyamanan, juga suasana ruang yang mencerminkan adanya sebuah harapan dan perubahan kedepan untuk mereka juga suasana ruang yang tidak menyadarkan mereka bahwa mereka dalam proses pelatihan (untuk menghindari rasa tertekan, suasana ruang yang nyaman).

Dalam jurnal ini, penulis menyadari bahwa masih banyak kekurangan. Sangat diharapkan adanya pendapat dan saran dari para pembaca, untuk perancangan kedepan yang lebih baik.

\section{REFERENSI}

5 Cara Generasi Millennial Mengubah Budaya Kerja Dan Desain. (2018, Juli 11). Retrieved from www.arginuring.com: https://www.arginuring.com/blog/tag/generasi-millennial/

9 Perilaku Milenial Indonesia. (2018, Agustus 20). Retrieved from www.provoke-online.com: http://www.provoke-online.com/index.php/special/18130-9-perilaku-milenial-indonesia

Ali, H. (n.d.). Memahami Millennial Indonesia. Retrieved from www.academia.edu: https://www.academia.edu/35915408/MEMAHAMI_MILENIAL_INDONESIA_by._Alvara_R esearch_Center

BUILD FUTURE LEADERS OF CHARACTER. (n.d.). Retrieved from Character First Education: http://characterfirsteducation.com/c/curriculum.php

Carnegie, D. (2019). Our Unique Approach. Retrieved from www.dalecarnegie.com: https://www.dalecarnegie.com/en/approach/process

Hum, N. (n.d.). Character Education. Retrieved from www.sutori.com: https://www.sutori.com/story/the-history-of-character-education--

SZo7nRz6fQeD5HdrAUWcSwH1

Human Comfort in Building. (2019, Januari 2). Retrieved from www.designingbuildings.co.uk: https://www.designingbuildings.co.uk/wiki/Human_comfort_in_buildings

INFOGRAFIS: Millenial ogah terlibat sepenuhnya di perusahaan? (2015, November 16). Retrieved from Rappler.com: https://www.rappler.com/indonesia/gaya-hidup/187169-infografismillenial-ogah-terlibat-perusahaan

Kelly Bear C.A.R.E.S. Curriculum. (n.d.). Retrieved from Kelly Bear: http://www.kellybear.com/KB_Program-C.A.R.E.S.html

McCray, F. D. (n.d.). Changes and Transformations in the Philosophy of Character Education in the 20th. 7.

(2018). Millennials disappointed in business, unprepared for Industry 4.0 . Deloitte. Retrieved from https://www2.deloitte.com/global/en/pages/aboutdeloitte/articles/millennialsurvey.html

Nuring, A. (2018, April 3). Bagaimana Generasi Millenia Merubah Trend Desain. Retrieved from www.arginuring.com: https://www.arginuring.com/blog/2018/04/03/1239/

PENGERTIAN PELATIHAN CHARACTER BUILDING. (2017, April 28). Retrieved from reframepositive.com: http://reframepositive.com/pengertian-pelatihan-characterbuilding/ 
Peta Zonasi \& Tata Ruang Jakarta. (n.d.). Retrieved from sindikat.co.id: http://www.sindikat.co.id/zonasi

Saint-Gobain. (2018, Juli). Millennials: Membentuk Gaya Arsitektur Masa Depan? Retrieved from www.id.weber: https://www.id.weber/en/node/516

Sinek, S. (2018, Mei 22). BEST SPEECH EVER - Simon Sinek on Millennials in the Workplace I SO INSPIRING!

Social-Emotional Learning and Character Development Training . (2019). Retrieved from calsac.org: https://www.calsac.org/socialemotional-learning-and-character-developmenttraining/

Subcommittee, W. (2017, Maret 23). EDUCATIONAL FACILITIES. Retrieved from www.wbdg.org: http://www.wbdg.org/building-types/educational-facilities

Subcommittee, W. S. (2017, April 4). TRAINING FACILITY . Retrieved from www.wbdg.org: http://www.wbdg.org/building-types/education-facilities/training-facility

Tanis, H. (2013). PENTINGNYA PENDIDIKAN CHARACTER BUILDING. 8.

The evolution of educational systems through history. (2015, September 14). Retrieved from mobileworldcapital.com: https://mobileworldcapital.com/2015/09/14/the-evolution-ofeducational-systems-through-history/

The Path to Education Transformation. (n.d.). Retrieved from www.intel.com: https://www.intel.com/content/www/us/en/education/solutions/educationtransformation-path-video.html

Training Facility. (2017, April 4). Retrieved from wbdg.org: http://www.wbdg.org/buildingtypes/education-facilities/training-facility

Watz, M. (2011). An Historical Analysis of Character Education. Journal of Inquiry \& Action in Education, 4(2), 20.

Why We Need Character Education. (2013). Virginia Journal of Education. 